\title{
MONOGRAFIE/MONOGRAPH
}

Valérie Tothová, Věra Hellerová (eds) (2021). Využití měřicích nástrojů v ošetřovatelství [Use of measuring instruments in nursing]. Praha. NLN, s. r. o. 225 s. ISBN 978-80-7422-817-9. DOI: 10.32725/zsf.2021.74228179

\section{Připravenost studentů na setkání s péčí o umírající pacienty a se smrtí} kap. 9: DOI: 10.32725/zsf.2021.74228179.07

\section{Inka Kratochvilová}

University of South Bohemia in České Budějovice, Faculty of Health and Social Sciences, Institute of Nursing, Midwifery and Emergency Care, České Budějovice, Czech Republic

\section{Souhrn}

Podíváme-li se mezi laickou veřejnost a někdy bohužel i mezi zdravotníky, zjistíme častokrát, že koncept paliativní péče není známý. Jednou z oblastí, na které bychom měli zapracovat, je tedy osvěta. Ta by mohla přispět $\mathrm{k}$ rozšíření povědomí zejména o možnostech hospicové péče jak kamenné, tak mobilní.

Nelze jednoznačně říct, jaké prostředí a přístup k péči o umírajícího pacienta je nejlepší. Vše by se mělo odvíjet od individuálních preferencí jednotlivce a jeho rodiny. At už však pacient stráví poslední chvíle kdekoliv, je důležité, aby měl dostatečný a patřičný př́istup $k$ paliativní péči. Jelikož je péče o umírající pacienty komplexní, vysoce individualizovaná a orientovaná na specifická přání a potřeby pacienta a jeho blízkých, nese s sebou také vysoké nároky na zdravotnický personál. Z tohoto hlediska je nutné, aby byla zajištěna kvalitní profesní príprava a následně př́liv odborníků pro tento obor.

Klíčová slova: měřicí nástroje, nelékařské zdravotnické obory, student, paliativní péče

\section{Podkapitoly:}

9.1 Aktuální vzdělávání v oblasti paliativní péče

9.2 Nástroje pro měření připravenosti zdravotníků na poskytování paliativní péče 9.3 Hodnocení připravenosti studentů nelékařských zdravotnických oborů ZSF JU 9.4 Připravenost a postoje studentů k paliativní péči

\section{Literatura}

1. Abdel-Khalek, A. M., Neimeyer, R. A. (2017). Death Anxiety Scale. In: Zeigler-Hill, V., Shackelford, T. K. (Eds). Encyclopedia of Personality and Individual Differences. Cham: Springer International Publishing AG.

2. Bártlová, S. (2005). Sociologie medicíny a zdravotnictví. 6., přeprac. a doplněné vyd. Praha: Grada, $188 \mathrm{~s}$.

3. Braun, M., et al. (2010). Associations between oncology nurses' attitudes toward death and caring for dying patients. Oncol Nurs Forum 37(1): E43-E49. DOI: 10.1188/10.ONF.E43-E49.

4. Bužgová, R., Janíková, E. (2017). Czech Adaption of the Collett-Lester Fear of Death Scale in a Sample of Nursing Students. Omega - J Death Dying 80(1): 20-34. DOI: 10.1177/0030222817725183.

5. Bužgová, R., Sikorová, L. (2013). Moral judgment competence of nursing students in the Czech Republic. Nurse Educ Today 33(10): 1201-1206. DOI: 10.1016/j.nedt.2012.06.016. 
6. $\mathrm{COH}, \mathrm{AACN}$ - City of Hope, American Association of Colleges of Nursing (2011). End of Life Nursing Education Consortium - International Training Program. Duarte: AACN.

7. Collett, L. J., Lester, D. (1969). The fear of death and the fear of dying. J Psychol 72(2): 179-181. DOI: 10.1080/00223980.1969.10543496.

8. Connor, S. R., Sepulveda Bermedo, M. C. (Eds). (2014). Global atlas of palliative care at the end-of-life. London: Worldwide Palliative Care Alliance \& World Health Organization.

9. ČSú (2020). Pohyb obyvatelstva - rok 2019. In: Czso.cz [online] [cit. 2020-11-03]. Dostupné z: https://www.czso.cz/csu/czso/cri/pohyb-obyvatelstva-rok-2019

10. Edo-Gual, M., et al. (2018). Spanish Adaptation of the Frommelt Attitude Toward Care of the Dying Scale (FATCOD-S) in Nursing Undergraduates. Omega (Westport) 78(2): 120-142. DOI: 10.1177/0030222816688294.

11. Frommelt, K. H. (1991). The effects of death education on nurses' attitudes toward caring for terminally ill persons and their families. Am J Hosp Palliat Care 8(5): 37-43. DOI: 10.1177/104990919100800509.

12. Frommelt, K. H. (2003). Attitudes toward care of the terminally ill: An educational intervention. Am J Hosp Palliat Care 20(1): 13-22. DOI: 10.1177/104990910302000108.

13. Henoch, I., et al. (2014). The Swedish version of the Frommelt Attitude Toward Care of the Dying scale: aspects of validity and factors influencing nurses' and nursing students' attitudes. Cancer Nurs 37(1): E1-E11. DOI: 10.1097/NCC.0b013e318279106b.

14. Kabelka, L., Sláma, O., Loučka, O. (2016). Paliativní péče v České republice 2016 - Situační analýza. Brno: Česká společnost paliativní medicíny ČLS J.E.P. [online] [cit. 2020-01-20]. Dostupné z: https://www.paliativnimedicina.cz/wp-content/uploads/2016/12/situacni-analyza-paliativni-pece.pdf

15. Kisvetrová, H., et al. (2017). Dying Care Nursing Intervention in the Institutional Care of End-of-Life Patients. Int J Nurs Knowl, 28(3): 131-137. DOI: 10.1111/2047-3095.12128.

16. Kratochvílová, I., et al. (2021). Hodnocení připravenosti studentů na setkání s umírajícím pacientem a se smrtí. Florence 21(1): 26-27.

17. Leombruni, P., et al. (2015). Confirmatory factor analysis of the Frommelt Attitude Toward Care of the Dying Scale (FATCOD-B) among Italian medical students. Palliat Support Care 13(5): 1391-1398. DOI: $10.1017 /$ S1478951515000139.

18. Mallory, J. L. (2003). The impact of a palliative care educational component on attitudes toward care of the dying in undergraduate nursing students. J Prof Nurs 19(5): 305-312. DOI: 10.1016/s87557223(03)00094-2.

19. Matsui, M., Braun, K. (2010). Nurses' and care workers' attitudes toward death and caring for dying older adults in Japan. Int J Palliat Nurs 16(12): 593-598. DOI: 10.12968/ijpn.2010.16.12.593.

20. Murtagh, F. E. M., et al. (2014). How many people need palliative care? A study developing and comparing methods for population based estimates. Palliat Med 28(1): 49-58. DOI: 10.1177/0269216313489367.

21. Nehrke, M. F., et al. (1978). Death anxiety, locus of control and life satisfaction in the elderly: Toward a definition of ego-integrity. Omega - J Death Dying 8(4): 359-368. DOI: 10.2190/7CKO-QFF8-HQJE-MHUP.

22. Paul, S. S., et al. (2019). Creating a Positive Attitude toward Dying Patients among Nursing Students: Is the Current Curriculum Adequate? Indian J Palliat Care 25(1): 142-146. DOI: 10.4103/IJPC.IJPC_148_18.

23. Pracovní skupina ke Koncepci paliativní péče v Jihočeském kraji (2018). Koncepce paliativní péče v Jihočeském kraji na období do roku 2023. České Budějovice: Krajský úřad Jihočeského kraje. [online] [cit. 2020-01-22]. Dostupné z: https://www.kraj-jihocesky.cz/file.php?par[id_r]=170028\&par[view]=0

24. Sadowska, A., et al. (2020). Assessment of the Reliability of the Polish Language Version of the FATCODB Scale Among Nursing Students. J Cancer Educ 36(3): 561-566. DOI: 10.1007/s13187-019-01665-5.

25. Thorson, J. A., Powell, F. C. (1994). Depression and Sense of Humor. Psychol Rep 75(3 Pt 2): $1473-1474$. DOI: 10.2466/pr0.1994.75.3f.1473.

26. ÚZIS, LPZ a NRHOSP 2011-2016 (2017). Struktura úmrtí podle místa. In: Koncepce paliativní péče v Jihočeském kraji na období do roku 2023. České Budějovice: Krajský úřad Jihočeského kraje. [online] [cit. 2020-03-17]. Dostupné z: https://www.kraj- 
jihocesky.cz/sites/default/files//ku_usneseni/Zastupitelstvo/2018-09-06/Navrhy/261-ZK-

18_Koncepce_paliativni_pece_v_Jihoceskem_kraji_na_obdobi_do_roku_202.pdf

27. Vávrová, S., Polepilová, R. (2010). Výzkumné šetření o vzdělávání studentů pomáhajících profesí v oblasti thanatologie. Sociální práce 2: 71-80. [online] [cit. 2020-05-30]. Dostupné z: http://

www.socialniprace.cz/index.php?sekce $=2 \&$ ukol $=$ detail\&id $=39 \&$ clanekid $=452$

28. Vyhláška č. 391/2017 Sb., kterou se mění vyhláška č. 55/2011 Sb., o činnostech zdravotnických pracovníků a jiných odborných pracovníků, ve znění vyhlášky č. 2/2016 Sb. In: Sbírka zákonů České republiky, částka 137.

29. Wang, L.-P., et al. (2016). Development and Psychometric Testing Chinese Version of the Frommelt Attitude Toward Care of the Dying Scale, Form B in Nurses and Nursing Students. J Cancer Educ 31(1): 123-130. DOI: 10.1007/s13187-015-0810-7.

30. ZSF JU (2020). Interní materiály - sylaby studijních oborů. České Budějovice: Zdravotně sociální fakulta Jihočeské univerzity. 